\title{
Extraction of Amylase from Fermentation Broth in Poly (Ethylene Glycol) Salt Aqueous Two-Phase System
}

\author{
Raquel Pedrosa Bezerra ${ }^{1,2}$, Fernanda Katharine Sousa Lins Borba ${ }^{1,2}$, Keila Aparecida \\ Moreira $^{2,3}$, José Luis Lima-Filho ${ }^{2}$, Ana Lúcia Figueiredo Porto ${ }^{2,4}$ and Adilson Castro \\ Chaves $^{1,2,5,6,7}$ \\ ${ }^{1}$ Instituto de Ciências Biológicas; Universidade de Pernambuco; Av. Agamenon Magalhães, s/n; 50100-010; Recife \\ - PE - Brasil. ${ }^{2}$ Laboratório de Imunopatologia Keizo Asami; Universidade Federal de Pernambuco; Av. Prof. \\ Moraes Rego, s/n; 50670-901; Recife - PE - Brasil. ${ }^{3}$ Doutorado em Ciências Biológicas; Centro de Ciências \\ Biológicas; Universidade Federal de Pernambuco; Av. Prof. Moraes Rego, s/n; 50670-901; Recife - PE - Brasil. \\ ${ }^{4}$ Departamento de Morfologia e Fisiologia Anima; Universidade Federal Rural de Pernambuco; R. Dom Manoel de \\ Medeiros, s/n; 52171-900; Recife - PE - Brasil. ${ }^{5}$ Laboratório de Biotecnologia; Faculdade de Formação de \\ Professores de Nazaré da Mata; Rua Prof. Américo Brandão, 43; 55800-000; Nazaré da Mata - PE -Brasil. ${ }^{6}$ União \\ das Escolas Superiores da FUNESO, Fundação de Ensino Superior de Olinda; Campus Universitário, s/n; \\ 53060-770; Olinda - PE - Brasil. ${ }^{7}$ Departamento de Patologia, Instituto de Ciências Biológicas; Universidade de \\ Pernambuco; Av. Agamenon Magalhães, s/n, 50100-010; Recife - PE - Brasil
}

\begin{abstract}
Studies were carried out on the partition of amylase from Bacillus subtilis in a minimal medium at $37^{\circ} \mathrm{C}$ and 110 rpm. Enzyme recovery was carried out in aqueous two-phase system PEG-Phosphate salt were carried out. The best purification factor (5.4) was obtained in system PEG 1000 (16.7\% w/w) with potassium phosphate (14.8\% w/w), at pH 6.0, resulting in a recovery of $45.2 \%$ activity enzymatic in the salt-rich phase.
\end{abstract}

Key words: Amylases, aqueous two-phase systems, Bacillus subtilis, partition, poly (ethylene glycol).

\section{INTRODUCTION}

Amylases are extracellular enzymes of great industrial interest. They are involved in the hydrolysis of starch molecules (Paquet et al., 1991), decomposing them in glucose. Starch is a major source of carbohydrates in the nature, being an abundant carbon source. Every starch polysaccharide molecule possesses one reducing terminal, able to reduce dinitrosalicylic acid; therefore, measurement of reducing sugars is an useful method to determine the molar concentration of starch molecules in solution. Amylases possess important applications in the production of syrup with high glucose content, sweetener manufacture, nourishing, detergents and ethanol. Other applications include textile and paper industries. Amongst amylolytic enzymes, $\alpha$ amylases, $\beta$-amylases, glucoamylase, pullulanase and isoamylase can be found, being the former two of bigger economic interest (Pandey et al., 2000). There are several sources for the production of amylases, such as bacteria, fungi and plants. Bacillus spp. is considered the most important source of amylase. Bacterial $\alpha$-amylase, however, is preferred over fungal amylase due to several characteristic advantages that it offers. The $\beta$ amylase has generally been obtained from plant sources. Filamentous fungi apparently constitute 
the major source of glucoamylase among all microbes (Pandey et al., 2000).

In order to perform large-scale purification of enzymes and proteins an efficient downstream processing technique amenable to preserve biological activity is needed (Tanuja et al. 1997).

Extraction in aqueous two-phase system (ATPS) is a suitable method for the first step of a separation procedure removing some contaminants in a simple and economic process (Chaves et al. 2000; Hatti-Kual 1996; Kula et al. 1982). Aqueous twophase systems are based on water-soluble polymers and salts and/or two different watersoluble polymers. Phase separation occurs over certain concentrations of the phase components. The binodial line is the boundary condition of concentrations for phase separation. Above the binodial line, the phase component separates to the upper phase and the lower phases. However, below the binodial line, one mixed phase exists (Albertsson 1986). The overall composition of phase-forming components has been exploited to influence the phase preference of proteins (Kula et al. 1982). Two-phase systems made by organic solvent and aqueous solution are being used for separation. Two-phase systems sometimes cannot be applied to the separation of active biological materials, which require mild aqueous environments. On the others hand, ATPS have low osmotic pressure, high water, buffering effects added salts and very low interfacial tension between the upper and the lower phases (Albertsson 1986). Aqueous two-phase systems have been used for separating plant and animal cells, cell organelles, membranes, enzymes, nucleotides and other biological materials (Albertsson 1986; Kohler et al. 1993). The aqueous two-phase systems have been designed for scale up of downstream processes for biomaterial separation (King 1992; Mistry et al. 1993). Partition characteristics depend on surface hydrophobicity; specific-binding sites on the surface properties of the biological materials which will be separated (Albertsson et al. 1970; Walter 1977). This separation procedure, i.e. partition, is influenced by phase system parameters, such as the molecular weight of the polymer, $\mathrm{pH}$, type and concentration of phase forming components (Chaves et al. 2000). The PEG/salt system is suitable for downstream processing of amylase, due to its high capacity biocompatibility and low costs. The aim of this work was to study the recovery of amylase through ATPS, properties such as $\mathrm{pH}$ and temperature stability of the crude and partially purified extract determined.

\section{MATERIALS AND METHODS}

\section{Reagents}

PEG (1000, 3350 and 8000) was obtained from Sigma (St. Louis, MO, USA). All other reagents are of analytical grade.

\section{Microorganism}

Bacillus subtilis DA 15 was obtained from the Department of Antibiotics-UFPE.

\section{Amylase production}

Bacillus subtilis was grown in fermentation medium described by Haddaoui et al. (1999) which contained the following components: minimal medium supplemented with $1 \%(\mathrm{w} / \mathrm{v})$ glucose and $0.1 \mathrm{mM} \mathrm{CaCl}$ in a $110 \mathrm{rpm}$ rotary shaker at $37^{\circ} \mathrm{C}$, during six hours. The fermentation broth was centrifuged for 15 minutes at $12500 \mathrm{x}$. The supernatant was used as enzyme source.

\section{$\alpha$-Amylase activity assay}

The activity of extracellular amylase was estimated by determining the amount of reducing sugars released from starch. The sugars were quantified by the method of 3,5-dinitrosalicylic acid (DNSA), according to Miller (1959). The starch solution was prepared from $1 \%(\mathrm{w} / \mathrm{v})$ soluble starch in $0.1 \mathrm{M}$ citrate/phosphate buffer $\mathrm{pH}$ 6.6 , at $37^{\circ} \mathrm{C}$. Volumes of $0.25 \mathrm{ml}$ of the enzymatic extract were added to $2.5 \mathrm{ml}$ of the starch solution and the mixture incubated at $37^{\circ} \mathrm{C}$ in a water bath for $10 \mathrm{~min}$. After $1 \mathrm{ml}$ of mixture was added to 2 $\mathrm{ml}$ of DNSA and boiled at $100^{\circ} \mathrm{C}$ for 10 minutes. The amount of reducing sugars in the final mixture was determined spectrophotometrically at $570 \mathrm{~nm}$. One unit of enzymatic activity is defined as the amount of enzyme that produces $1 \mu \mathrm{mol} / \mathrm{min}$ of glucose. The specific activity is expressed as units per milligrams of protein. The calibration curve for DNSA was established with several standard solutions of glucose ranging from $100 \mu \mathrm{g} \mathrm{ml}^{-1}$ to $500 \mu \mathrm{g} \mathrm{ml}^{-1}$ 


\section{Protein quantification}

Protein content was determinated using the method described by Bradford (1976) with bovine serum albumin as standard.

Effects of $\mathrm{pH}$ and temperature on amylase activity

Amylase activity was measured at different $\mathrm{pH}$ and temperature values using starch as substrate. The enzyme activities, before and after purification, were assayed using $1 \%(\mathrm{w} / \mathrm{v})$ starch in $0.1 \mathrm{M}$ citrate/phosphate buffer solution $(\mathrm{pH}$ ranging from $4.0-7.0$ ). The $\mathrm{pH}$ optimum assays, the enzyme were incubated at $25^{\circ} \mathrm{C}$, for 10 minutes, in buffers solutions of different $\mathrm{pH}$ values. The amylase activity was also assayed at various temperatures $\left(40^{\circ}-100^{\circ} \mathrm{C}\right)$ at $\mathrm{pH}$ 6.6.

\section{Preparation of the two-phase systems}

The systems (total mass 6g) were prepared from stock solutions of the polymers $50 \%(\mathrm{w} / \mathrm{w})$ (PEG 1000,3350 and 8000) in water, and 40\% (w/w) salt stock solution as a mixture of potassium phosphate monobasic, potassium phosphate dibasic. All the systems, in duplicate, were prepared in graduated centrifuge tubes. The PEGphosphate salts systems were assumed to be close the original phosphate stock solution $(\mathrm{pH} \mathrm{6.0,} \mathrm{7.0,}$ 8.0). The partition experiments were performed at room temperature $\left(25 \pm 2^{\circ} \mathrm{C}\right)$ by mixing the systems with crude extract from fermentation $(1 \mathrm{ml})$. After separation of the phases by centrifugation for $236 \mathrm{x} \mathrm{g}$, samples of each phase were taken with a pipette for the quantification protein and activity of enzyme. The study of enzyme partitioning at different tie lines was carried out varying the PEG and salts concentrations as show on the Table 1.

Table 1 - Composition of the two phases system

\begin{tabular}{cccc}
\hline \multirow{2}{*}{ Polymer } & \multicolumn{3}{c}{ PEG $(\boldsymbol{\%}$ w/w) and salt $(\%$ w/w $)$} \\
& Tie line 1 & Tie line 2 & Tie line 3 \\
\hline PEG 1000 & $16.7 / 14.8$ & $17.7 / 15.7$ & $19.7 / 17.7$ \\
PEG 3350 & $14.0 / 11.8$ & $17.7 / 15.7$ & $19.7 / 17.7$ \\
PEG 8000 & $11.8 / 9.8$ & $14.0 / 11.8$ & - \\
\hline
\end{tabular}

Determination of the partition coefficient $(K)$ : The relative distribution of the enzyme in the aqueous two-phase system is characterized by the partition coefficient $(\mathrm{K})$, calculated according to the following equation:

$$
\mathrm{K}=\mathrm{C}_{\mathrm{t}} / \mathrm{C}_{\mathrm{b}}
$$

Where $C_{t}$ stands for enzyme activity in the top phase, $\mathrm{C}_{\mathrm{b}}$ enzyme activity in the bottom phase.

\section{Determination of the purification factor}

The purification factor $(\mathrm{PF})$ is defined as the ratio of the enzymatic specific activity of the crude extract by the enzymatic specific activity after purification.

$\mathrm{PF}=$ Enzyme specific activity after purification / Enzyme specific activity of crude extract.

\section{Determination of recovery enzymatic activity}

The recovery enzymatic activity is defined as the ratio of the enzymatic activity after purification by enzymatic activity of crude extract multiplied by 100.

REA = Enzymatic activity after purification $\mathrm{X}$ $100 /$ enzymatic activity of crude extract.

\section{RESULTS AND DISCUSSION}

Studies of amylase partition in the polyethylene glycol/phosphate system

The development of purification procedure using aqueous two-phase systems involves the variation of several factors until a good result is achieved. The partition coefficient, recovery of enzyme activity and factor of purification were studied to characterize the distribution of amylase between the two phases of the system. The enzyme partition in the ATPS depends on the size of the biomolecule, superficial properties, molecular 
load, ionic composition of the phases, polymer concentration and molecular length of the polymer (Harries et al. 1997).

\section{Effect of polymer molecular weight}

Fig. 1A, 1B and 1C indicated that the systems studied were slightly influenced by the PEG molecular mass. The partition coefficients showed no regular tendency in all the cases. This could be attributed to different two effects.

One of these effects was the increase in the upper phases hydrophobicty. In fact, as PEG chain length increased there were less hydroxyl groups for the same concentration of the polymer and hence the polymer-richer upper phase increased in hydrophobicy. On the other hand, the chain length increase also caused the increase of the excluded volume, which mean less space available for the protein in the PEG rich phase (Marcos et al. 1999). Similar behavior was observed by Marcos et al. (1999) and Almeida et al. (1998) studing the purification of penicillin acylase from Escherichia coli and cutinase from E. coli WK-6 recombinant, respectively, using poly (ethylene glycol)-sodium citrate and poly (ethylene glycol)- hydroxypropyl starch.

\section{Effect of the tie line length}

The partition coefficient (K) of $\alpha$-amylase in PEG (1000, 3350 and 8000)/phosphate systems are showed in Fig. 1A, 1B and 1C, respectively. In all systems studied in this work at $\mathrm{pH} 7.0$, with increasing the tie line length, $\mathrm{K}$ of enzyme decrease. This effect was caused by the increasing PEG concentration witch cause continuous molecular exclusion of amylase from the top to bottom phases, following continuous reequilibration of the levels in both phases. The same didn't occur in PEG 8000 system at $\mathrm{pH}$ 8.0, where there was no significant difference in the $\mathrm{K}$ value. Study carried by Almeida et al. 1998, Furuya et al. 1995 and Chaves et al. 2002 for the extraction of cutinase in the PEG 4000/hydroxypropyl starch, hydrolytic enzyme in PEG-dextran system and extraction of Sm-13 recombinant antigen from Escherichia coli in the PEG (1000, 3350 and 8000)/Reppal PES 100 system, respectively, showed that the partition coefficients were significantly influenced by the PEG molecular weight. Ortin et al. (1991), studying the partition of $\alpha$-lactoalbumin and $\beta$ - lactoglobulin in PEG/hydroxypropyl starch systems, showed that the increase of the tie line resulted protein displacement to the bottom phase, thus decreasing the $\mathrm{K}$ value. Further studies with bovine serum albumin accomplished by Christian et al. (1998) also showed the decrease of K with the increase of the length tie line in the PEG 3350/arabinogalactan system. Cunha et al. (2003) studied the extraction of recombinant and wild cutinase observing that wild cutinase had a tendency for salt rich phase, similar results was obtained in present work.

Table 2, 3 and 4 show the effects of the tie line length in different PEG-phosphate system.

In the PEG 3350 and 8000/phosphate system at $\mathrm{pH}$ 6.0 , a decrease of recovery of enzyme activity (REA) and purification factor (PF) was observed with the increase of the tie line length in both phases. Similar was noted for PEG 3350 and 1000/ salts systems at pH 7.0 (Table 2 and 3, respectively).

Bottom phases, following continuous reequilibration of the levels in both phases. The same didn't occur in PEG 8000 system at $\mathrm{pH}$ 8.0, where there was no significant difference in the $\mathrm{K}$ value. Study carried by Almeida et al. (1998), Furuya et al. (1995) and Chaves et al. (2002) for the extraction of cutinase in the PEG 4000/hydroxypropyl starch, hydrolytic enzyme in PEG-dextran system and extraction of Sm-13 recombinant antigen from Escherichia coli in the PEG (1000, 3350 and 8000)/Reppal PES 100 system, respectively, showed that the partition coefficients were significantly influenced by the PEG molecular weight. Ortin et al. (1991), studying the partition of $\alpha$-lactoalbumin and $\beta$ lactoglobulin in PEG/hydroxypropyl starch systems, showed that the increase of the tie line resulted protein displacement to the bottom phase, thus decreasing the $\mathrm{K}$ value. Further studies with bovine serum albumin accomplished by Christian et al. (1998) also showed the decrease of K with the increase of the length tie line in the PEG 3350/arabinogalactan system. Cunha et al. (2003) studied the extraction of recombinant and wild cutinase observing that wild cutinase had a tendency for salt rich phase, similar results was obtained in present work. 
PEG 1000

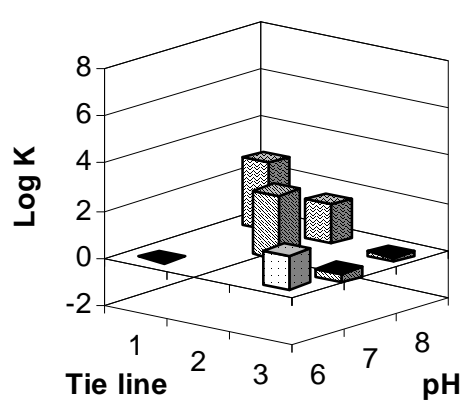

PEG 3350

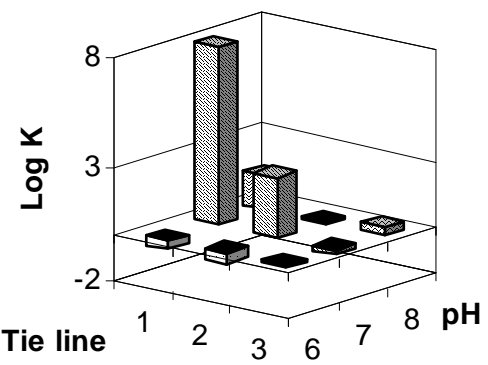

PEG 8000

C

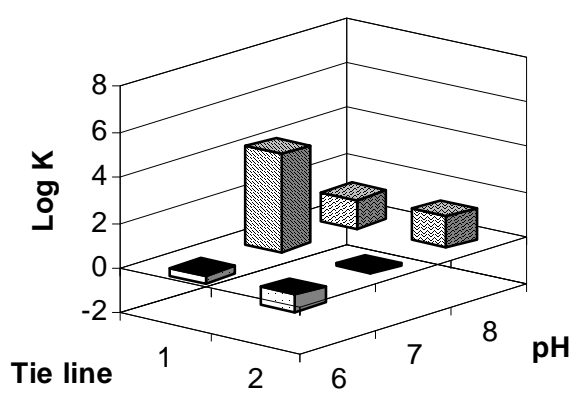

Figure 1 - Effect of tie line length and pH in log K for PEG 1000 (A); PEG 3350 (B); and PEG 8000 (C).

Table 2 - Purification factor and recovery of amylase activity in the PEG 1000/salt systems

\begin{tabular}{|c|c|c|c|c|c|c|c|c|c|c|}
\hline \multicolumn{2}{|c|}{ Tie line } & \multicolumn{3}{|c|}{1} & \multicolumn{3}{|c|}{2} & \multicolumn{3}{|c|}{3} \\
\hline & $\mathbf{H}$ & 6 & 7 & 8 & 6 & 7 & 8 & 6 & 7 & 8 \\
\hline \multirow{2}{*}{ REA (\%) } & Top phase & 33.8 & $*$ & 22.7 & $*$ & 43.8 & 14.3 & 44.8 & 10.4 & 22.8 \\
\hline & Bottom phase & 45.2 & $*$ & 25.2 & $*$ & 41.0 & 19.4 & 28.3 & 28.6 & 47.9 \\
\hline \multirow{2}{*}{ PF } & Top phase & 0.1 & * & 0.2 & $*$ & 0.2 & 0.05 & 0.2 & 0.01 & 0.04 \\
\hline & Bottom phase & 5.4 & $*$ & 0.3 & $*$ & 0.1 & 0.03 & 0.1 & 0.03 & 0.2 \\
\hline
\end{tabular}

REA - recovery of enzyme activity; PF-purification factor;

* - Formation of phases was not observed 
$\underline{\text { Table } 3 \text { - Purification factor and recovery of amylase activity in the PEG 3350/salt systems }}$

\begin{tabular}{|c|c|c|c|c|c|c|c|c|c|c|}
\hline \multirow{2}{*}{\multicolumn{2}{|c|}{$\begin{array}{c}\text { Tie line } \\
\text { pH }\end{array}$}} & \multicolumn{3}{|c|}{1} & \multicolumn{3}{|c|}{2} & \multicolumn{3}{|c|}{3} \\
\hline & & 6 & 7 & 8 & 6 & 7 & 8 & 6 & 7 & 8 \\
\hline \multirow{2}{*}{ REA (\%) } & Top phase & 18.7 & 19.1 & 32.0 & 43.0 & 18.5 & 13.0 & 7.8 & 14.0 & 36.3 \\
\hline & Bottom phase & 55.3 & 39.2 & 18.3 & 16.0 & 32.4 & 30.0 & 42.8 & 25.9 & 30.0 \\
\hline \multirow{2}{*}{$\mathbf{P F}$} & Top phase & 1.8 & 0.4 & 0.5 & 1.0 & 0.8 & 0.2 & 0.8 & 0.6 & 1.0 \\
\hline & Bottom phase & 3.8 & 0.5 & 0.7 & 1.9 & 0.3 & 1.3 & 3.5 & 3.0 & 2.8 \\
\hline
\end{tabular}

REA- recovery of enzyme activity; PF- purification factor.

Table 4 - Purification factor and recovery of amylase activity in the PEG 8000/salt systems

\begin{tabular}{|c|c|c|c|c|c|c|c|}
\hline \multirow{2}{*}{\multicolumn{2}{|c|}{$\begin{array}{c}\text { Tie line } \\
\text { pH }\end{array}$}} & \multicolumn{3}{|c|}{1} & \multicolumn{3}{|c|}{2} \\
\hline & & 6 & 7 & 8 & 6 & 7 & 8 \\
\hline \multirow{2}{*}{ REA $(\%)$} & Top phase & 22.4 & 12.4 & 40.5 & 18.9 & 27.1 & 40.1 \\
\hline & Bottom phase & 46.1 & 64.8 & 41.9 & 30.2 & 23.7 & 26.6 \\
\hline \multirow{2}{*}{$\mathbf{P F}$} & Top phase & 1.1 & 0.3 & 0.8 & 0.3 & 1.3 & 1.8 \\
\hline & Bottom phase & 1.5 & 2.3 & 0.8 & 0.9 & 0.3 & 1.3 \\
\hline
\end{tabular}

REA - recovery of enzyme activity; PF- purification factor.

$*$ - Formation of phases was not observed

Table 2, 3 and 4 show the effects of the tie line length in different PEG-phosphate system. In the PEG 3350 and 8000/phosphate system at $\mathrm{pH}$ 6.0 , a decrease of recovery of enzyme activity (REA) and purification factor (PF) was observed with the increase of the tie line length in both phases. Similar was noted for PEG 3350 and 1000/ salts systems at $\mathrm{pH} 7.0$ (Table 2 and 3, respectively).

\section{Effect of pH}

As general rule, negatively charged proteins prefer the upper PEG-rich phase and positively charged proteins partition to the lower phase (Schmidt et al. 1994). As the $\mathrm{pH}$ increases above the isoelectric point $(\mathrm{pI})$ of a protein, it becomes negatively charged, its interaction with PEG becomes stronger (Huddleston et al. 1991), and the partition coefficient increases. In the system PEG 1000/ phosphate (Fig. 1A) it was observed that it did not have a regular trend. However, in systems with the biggest molecular weight, an increase of the coefficient of partition occurred with the increase of $\mathrm{pH}$ (Figs. 1B and 1C). Same results were obtained by Xu et al. (2002) who studied the extraction of glucose-6-phosphate dehydrogenase and hexokinase in PEG/PES systems. Wu et al. (2001), working with two consecutive aqueous two phase extraction steps in PEG 8000/polyvynilalcohol system, followed in PEG $8000 /\left(\mathrm{NH}_{4}\right)_{2} \mathrm{SO}_{4}$ system, observed strong partitioning of endo- polygalacturonase into the bottom phase with the increase of $\mathrm{pH}$. The results presented in PEG (3350 and 8000)/ phosphate systems (Table 3 and 4 , respectively), tie line 1 , demonstrated that $\mathrm{PF}$ decreased with increasing $\mathrm{pH}$. Increase of $\mathrm{pH}$ resulted a decrease of PF. Similar behavior was obtained in the PEG 1000 and 3350 at tie line 2 (Table 2 and 3). However, except in the PEG 8000 at $\mathrm{pH} 8.0$, tie line 1 , no observed a significant difference in the recovery of the enzymatic activity in the bottom phase $(41.9 \%)$ and in the top phase $(40 \%)$ were no observed (Table 4$)$. In this system was observed recovery maximum of enzymatic activity $(64.8 \%)$ occurred in the bottom phase, tie line 1, at $\mathrm{pH}$ 7.0. In present work highest purification factor (5.4) was obtained at $\mathrm{pH} 6.0$, tie line 1 in the salt-rich phase of PEG 1000 (Table 2).

Effect of $\mathrm{pH}$ and temperature in amylase activity in crude extract and partially purified extract

The profile of $\mathrm{pH}$ and temperature over the enzymatic activity of amylase were evaluated before and after purification. Fig. 2A shows the optimum $\mathrm{pH}$ of the crude extract before and after purification in the PEG/salt system (PEG 1000, tie line 1, $\mathrm{pH}$ 6.0). An optimal $\mathrm{pH}$ was obtained at $\mathrm{pH}$ 5.0 for both the samples (crude extract and partially purified extract). As shown in Fig. 2B, the optimal temperature was $60^{\circ} \mathrm{C}$, in both the samples. In general, these results were in 
agreement with studies carried out by Tigue et al. (1994); Dercová et al. (1992) and Swamy et al. (1995) workingwith B. flathermus, B. subtilis and Clostridium thermosulfurogenes, respectively, on the production amylase. The results demonstrated that after the purification with PEG 1000/phosphate system there was no change in the optimal $\mathrm{pH}$ and temperature of the amylase.
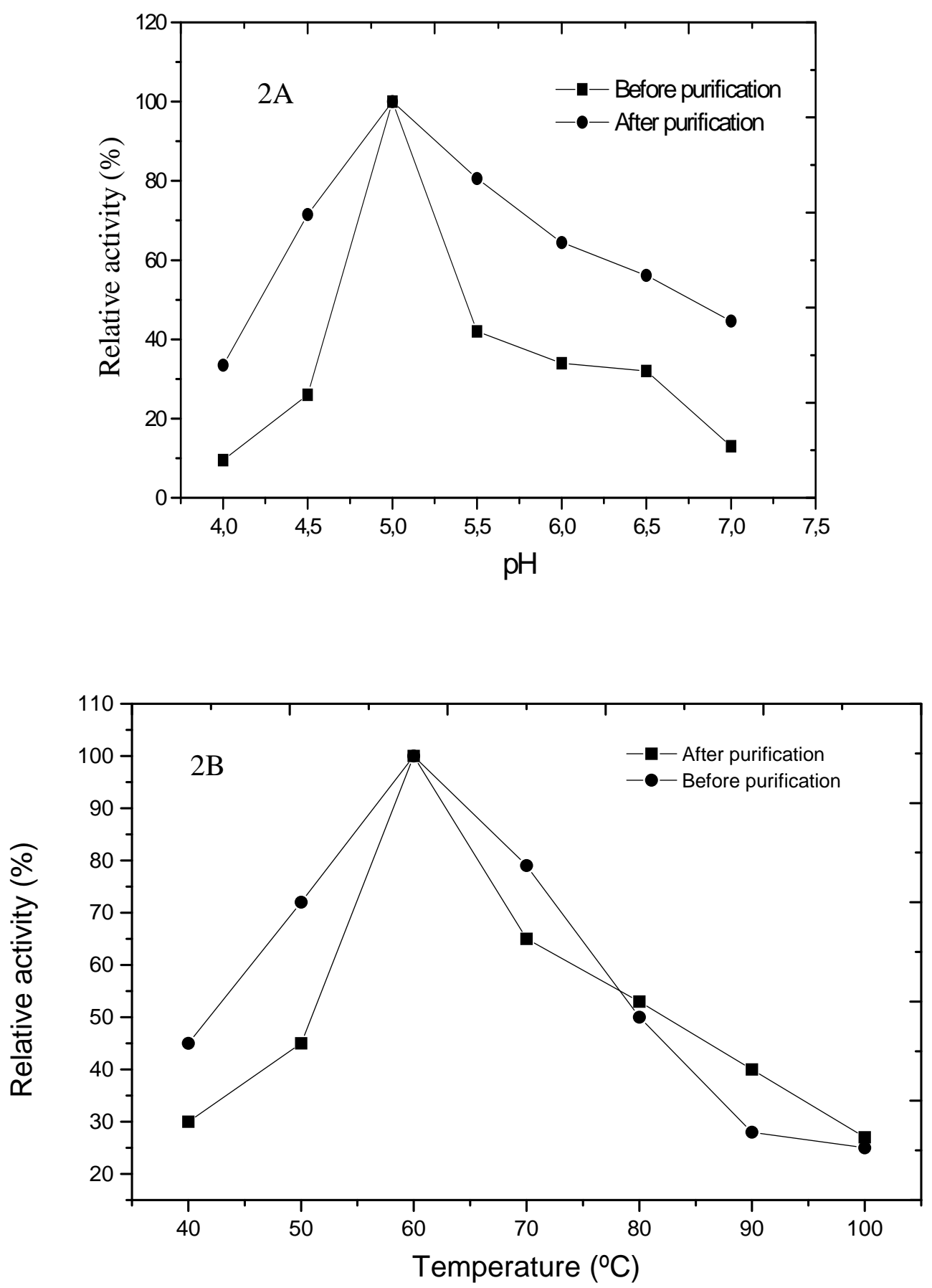

Figure 2 - Effect of $\mathrm{pH}(\mathrm{A})$ and temperature (B) on amylase activity before and after purification in the PEG 1000/phosphate system. 


\section{ACKNOWLEDGEMENTS}

This work was supported by Federal University of Pernambuco, University of Pernambuco and Rural Federal University of Pernambuco.

\section{RESUMO}

Enzimas amilolíticas têm sido amplamente investigadas com a finalidade de melhorar os processos industriais para a degradação do amido. Foi determinado que a extração da enzima em sistema bifásico aquosos é um método aplicável para separação e purificação de biomoléculas em misturas. Vários sistemas compostos de soluções aquosas de polietilenoglicol e fosfato foram avaliados. Estudos de produção em meio mínimo suplementado, à $37^{\circ} \mathrm{C}$, com uma velocidade de agitação de $110 \mathrm{rpm}$ e recuperação da amilase a partir do Bacillus subtilis em sistema bifásico aquoso PEG-fosfato foram avaliados. O melhor fator de purificação (5.4) foi obtido no sistema PEG $1000(16.7 \% \mathrm{w} / \mathrm{w})$ com fosfato de potássio $(14.8 \%$ w/w), a pH 6.0, resultando na recuperação da atividade enzimática de $45.2 \%$ na fase rica em sal.

\section{REFERENCES}

Albertsson, P. A. (1986), Partition of Cellular Particles and Macromolecules. $3^{\text {rd }}$ ed. New York: Wiley.

Albertsson, P. A.; Sasakawa, S. and Walter, H. (1970), Cross-partition and isoelectric points of proteins. Nature, 228, 1329-1330.

Almeida, M. C.; Venâncio, A.; Teixeira, J. A. and Aires-Barros, M. R. (1998), Cutinase purification on poly (ethylene glycol)-hydroxypropyl starch aqueous two-phase systems. Journal of Chromatography B, 711, 151-159.

Bradford, M. M. (1976), A rapid and sensitive method for the quantitation of microgram quantities of protein utilizing the principle of protein-dye binding. Analytical Biochemistry, 72, 248-254.

Chaves, A. C.; Silveira, E.; Bezerra, R. P.; Moreira, K. A.; Lucena-Silva, N. L. C.; Abath, F. G. C.; Porto, A. L. F.; Cabral, J. M. S. and Lima-Filho, J. L. (2002), Influence of partition parameters on a recombinant antigen of Schistosoma mansoni expressed on E. coli using poly (ethylene glycol)-hydroxyropyl starch aqueous two-phase system. World Journal of Microbiology and Biotechnology, 18, 645-648.
Chaves, A. C.; Lucena-Silva, N. L. C.; Abath, F. G. C.; Pereira, V. R. A.; Lima-Filho, J. L.; Porto, A. L. F. and Cabral, J. M. S. (2000), Liquid-liquid extraction Schistosoma mansoni recombinat protein from an $E$. coli extract in aqueous two-phase system. Bioprocess Engineering, 23, 435-438.

Cunha, M. T.; Costa, M. J. L.; Calado, C. R. C.; Fonseca, L. P.; Aires-Barros, M. R. and Cabral, J. M. S. (2003), Integration of production and aqueous twophase systems extraction of extracellular Fusarium solani pisi cutinase fusion proteins. Journal Biotechnology, 100, 55-64.

Christian, T. J.; Manley-Harris, M. and Richards, G. N. (1998), A preliminary study of the use of larch arabinogalactan in aqueous two-phase systems. Carbohydrate Polymers, 35, 7-12.

Decovà, K.; Augistin, J. and Krajcovà, D. (1992), Cell growth and $\alpha$-amylase production characteristics of Bacillus subtilis. Folia Microbiology, 37, 17-23.

Haddaoui, E.; Chambert, R.; Gatron, P.; Lindy, O. and Sarvas, M. (1999), Bacillus subtilis $\alpha$-amylase: the rate limiting step secretion is growth phaseindependent. Microbiology Letters, 173, 127-131.

Harris, D. P.; Andrews, A. L.; Wright, G.; Pyle, D. L. and Ansejo, M. (1997), The application of aqueous two phases systems two to the purification of pharmaceutical proteins from transgenic sheep milk. Bioseparation, 7, 31-37.

Hatti-Kaul, R. (1996), Aqueous two-phase systems: methods and protocols. Hardcover: Human. pp. 468.

Huddleston, J. G.; Ottomar, K. W.; Ngonyani, D. M. and Lyddiatt, A. (1991), Influence of system and molecular parameters upon fractionation of intracellular proteins from Saccharomyces by aqueous two-phase partition. Enzyme Microbiology Technology, 13, 24-27.

Hustedt, H.; Kroner K. H. and Kula M. R. (1985), In: Walter, H.; Brooks, D. E. and Fisher, D. Partitioning in aqueous two-phase system: theory, methods, uses, and application to biotechnology. New York: Academic. pp 529-587.

King, R. (1992), In: Soane, D. S. Polymer Applications for Biotechnology: Macromolecular Separation and Identification. Englewood: Prentice-Hall Polymer Science and Engineering Series. pp. 204-243.

Kula, M. R.; Kroner K. H. and Hustedt H. (1982), Purification of enzymes by liquid-liquid extraction. In: Fiechter, A. (Ed.). Advances in Biochemical Engineering: Reaction Engineering. New York: Spriger. pp. 74-118.

Kohler, K.; Nisson, B. and Veide, A. (1993), Recovery of extracellular human insulin-like growth factor-I and II as a fusion protein from Escherichia coli culture broth by aqueous two-phase extraction. Bioseparation, 3 : (4), 241-250. 
Kohler, K.; Veide, A. and Enfors, S. O. (1991), Partition of $\beta$-galactosidase fusion proteins in PEG/potassium phosphate aqueous two-phase systems. Enzyme Microbiology and Technology, 13, 204-209.

Li, M.; Kim, J. and Peeples, T. L. (2002), Amylase partitioning and extractive bioconversion of starch using thermoseparating aqueous two-phase systems. Journal Biotechnology, 93, 15-26.

Marcos, J. C.; Fonseca, L. P.; Ramalho, M. T., Cabral, J. M. S. (1999), Partial purification of penicillin acylase from Escherichia coli in poly(ethylene glycol)-sodium citrate aqueous two-phase systems Journal of Chromatography B, 734, 15-22.

Miller, G. L. (1959), Use of dinitrosalicylic acid reagent for determination of reducing sugars. Analytic Chemistry, 31, 426-428.

Mistry, S. L.; Ansejo J. A. and Zaror (1992-3), Mathematical modeling and simulation of aqueous two-phase continuous protein extraction. Bioseparation, 3 : (6), 343-358.

Ortin, A.; Cebrain, J. A.; López-Pérez, M. J. and Johansson, G. (1991), An aqueous hydroxypropyl starch-poly (ethylene glycol) two-phase system for extraction of $\alpha$-lactoalbumin and $\beta$-lactoglobulin from bovine whey. Bioseparation, 2, 197-205.

Pandey, A.; Nigam, P.; Soccol, C. R.; Scool, V. T.; Sign, D. and Mohan, R. (2000), Advances in microbial amylases. Biotechnology and Applied Biochemistry, 31, 135-152.

Paquet, V.; Croux, C.; Goma, G. and Soucaille (1991), Purification and characterization of the extracellular alpha amylase from Clostridium acetabutylicum ATCC 824. Applied Environmental Microbiology, 57, 212-218.

Schmidt, A. S.; Ventom, A. M. and Asenjo, J. A. (1994), Partitioning and purification of $\alpha$-amylase in aqueous two-phase systems. Enzyme Microbiology and Technology, 16, 131-142.
Swamy, M. V. and Seenaya, G. (1995), Thermostable pullulanase and $\alpha$-amylase activity from Clostridium Thermosulfurogenes SV9 - Optimization of culture conditions for enzyme production. Process Biochemistry, 31, 157-162.

Tanuja, S.; Scrinivas, N. D.; Rao, K. S. M. S. R. and Gowthman, M. K. (1997), Aqueous two phase extraction for downstream processing of amyloglucosidase. Process Biochemistry, 32 : (8), 635-641.

Tigue, M. A.; Kelly, C. T.; Fogarty, W. M. and Doyle, E. M. (1994), Production studies on the alkaline amylases of three alkalophilic Bacillus sp. Biotechnology Letters, 16, 569-574.

Zalavsky, B. Y. (1994), Aqueous Two-phase Partitioning: Physical Chemistry and Bioanalytical Application.. New York: Marcel Dekker. pp. 656.

$\mathrm{Xu}$, Y.; Vitolo, M.; Albuquerque, C. N. and Pessoa Jr., A. (2002), Affinity partitioning of glucose-6phosphate dehydrogenase and hexokinase in aqueous two-phase systems with free triazine dye ligands. Journal Chromatography B, 780, 53-60.

Walter H. (1977), Methods of Cell Separation. Nicholas Catsimpoolas, Plenum Press. New York: Perseus.

Wu, Y. T.; Pereira, M.; Venâncio, A. and Teixeira, J. (2001), Separation of endo-polygalacturonase using aqueous two-phase partitioning. Journal Chromatography A, 929, 23-29.

Received: December 12, 2004; Revised: October 06, 2005; Accepted: April 19, 2006 